\title{
Avaliação da matriz nutricional da enzima fitase em rações contendo sorgo para poedeiras comerciais ${ }^{1}$
}

\author{
Elaine Cristina Ligeiro ${ }^{2}$, Otto Mack Junqueira ${ }^{2}$, Rosemeire da Silva Filardi ${ }^{3}$, Antonio Carlos \\ de Laurentiz ${ }^{3}$, Karina Ferreira Duarte ${ }^{2}$, Patricia de Cassia Andrade Marchizeli ${ }^{2}$ \\ ${ }^{1}$ Financiado pela Fundação de Amparo à Pesquisa do Estado de São Paulo (FAPESP). \\ 2 Departamento de Zootecnia, Faculdade de Ciências Agrárias e Veterinárias de Jaboticabal - UNESP. \\ ${ }^{3}$ Departamento de Biologia e Zootecnia, Faculdade de Engenharia de Ilha Solteira - UNESP.
}

\begin{abstract}
RESUMO - Avaliaram-se os efeitos da inclusão de fitase e de sua matriz nutricional em rações contendo sorgo sobre o desempenho das aves, a qualidade dos ovos, a ingestão e a excreção e retenção de fósforo e nitrogênio em poedeiras comerciais. Utilizaram-se 180 poedeiras comerciais, distribuídas em delineamento inteiramente ao acaso em esquema fatorial $2 \times 2+1$, com dois níveis de fitase (0 e 500 FTU/kg de ração) e dois níveis de substituição do milho pelo sorgo (50 e $100 \%$ ) e uma ração testemunha (isenta de sorgo e fitase), constituindo cinco tratamentos com seis repetições de seis aves. As rações foram à base de milho e farelo de soja, sem fitase e sorgo, considerando a matriz nutricional da fitase. O desempenho e a qualidade dos ovos foram avaliados em quatro períodos de 28 dias. Ao final do experimento, um ensaio de metabolismo foi realizado para quantificar a ingestão, excreção e retenção aparente de fósforo e nitrogênio e avaliar a viabilidade econômica das rações. Ao considerar a matriz nutricional da fitase, as exigências em energia, cálcio, fósforo, proteína e aminoácidos foram atendidas, mesmo com a redução dos níveis nutricionais da dieta, e o desempenho e a qualidade dos ovos não foram comprometidos. A adição de fitase nas rações possibilitou reduzir todos os parâmetros econômicos avaliados. O sorgo pode substituir totalmente o milho e ser o único grão energético da dieta.
\end{abstract}

Palavras-chave: alimentos alternativos, avaliação econômica, aves, retenção aparente de fósforo e nitrogênio

\section{Evaluation of the nutritional matrix values for phytase enzyme in laying hens diets with sorghum}

\begin{abstract}
The effects were assessed of including phytase and its nutritional matrix in diets containing sorghum on the performance of the birds, egg quality, intake and phosphorus excretion and retention in laying hens. One hundred and eighty laying hens were arranged in a randomized complete design in a $2 \times 2+1$ factorial arrangement with two phytase levels ( 0 and $500 \mathrm{FTU} / \mathrm{kg}$ diet), two levels of corn replacement for sorghum (50 and 100\%) and a control diet (without phytase and sorghum) forming five treatments and six replications of six birds. The diets were based on corn and soybean meal, without phytase and sorghum, considering the phytase nutritional matrix. Performance and egg quality were determined in four 28-day periods. At the end of the experiment, a metabolism trial was carried out to quantify intake, excretion and apparent retention of phosphorus and nitrogen and to assess the economic viability of the diets. When the phytase nutritional matrix was considered, the energy, calcium phosphorus, protein and amino acid requirements were met, even with a reduction in the nutritional levels of the diet, and performance and egg quality were not affected. Adding phytase to the diets decreased all the economic parameters. Sorghum can be used to totally replace corn, and can be the only energy grain in the diet.
\end{abstract}

Key Words: alternative foods, apparent phosphorus and nitrogen retention, birds, economic assessment

\section{Introdução}

Atualmente a produção de aves requer maior atenção para diminuição nos custos com alimentação, garantia na segurança e qualidade do produto que chega ao consumidor e proteção ao meio ambiente. Nesse contexto, a utilização de ingredientes para substituir o milho e o farelo de soja e a inclusão de alguns aditivos não-alimentares, como as enzimas exógenas, são estratégias importantes para os nutricionistas.

Entre as enzimas disponíveis para utilização em rações para aves, a mais estudada e de maior eficácia é a fitase, 
produzida principalmente por microrganismos do gênero Aspergillus e com capacidade de hidrolisar o fitato, uma molécula que complexa o fósforo (Sebastian et al., 1998), alguns cátions (Gordon \& Roland, 1998), energia (Namkung \& Leeson, 1999) e aminoácidos (Sebastian et al., 1997), disponibilizando esses nutrientes para aproveitamento dos monogástricos.

Em estudos para avaliação dos efeitos da inclusão de fitase em rações para aves, evidenciou-se a possibilidade de redução nos níveis de fósforo total e na necessidade de fontes minerais de fósforo e excreção desse elemento para o ambiente (Laurentiz et al., 2007).

Assim como no milho e farelo de soja, a presença do fitato também reduz a disponibilidade de fósforo nos ingredientes que podem substituí-los. Entretanto os benefícios da utilização da fitase são evidenciados geralmente em dietas à base de milho e farelo de soja, portanto, são necessários mais estudos para se avaliar a relação custo/benefício da utilização dessa enzima em dietas contendo esses substitutos. Além disso, nos estudos com poedeiras, geralmente a matriz nutricional da fitase não é considerada no momento de formulação das rações.

No Brasil o sorgo representa o principal grão substituto do milho, que, além de ter valor nutricional semelhante, ainda tem a vantagem de apresentar mais de uma safra ao ano e ser menos exigente em água.

Alguns estudos com poedeiras têm comprovado que o sorgo pode substituir parcial ou totalmente o milho sem afetar o desempenho das aves, o que, no entanto, exige a utilização de uma fonte de carotenoides para garantir a pigmentação das gemas dos ovos (Casartelli et al., 2005; Assuena et al., 2008)

Neste trabalho avaliaram-se os efeitos da inclusão de fitase e de sua matriz nutricional em rações contendo sorgo sobre o desempenho, a qualidade dos ovos, a ingestão, a excreção e retenção aparente de fósforo e nitrogênio de poedeiras comerciais, além da avaliação econômica das rações.

\section{Material e Métodos}

O experimento foi conduzido no Setor de Avicultura da Faculdade de Ciências Agrárias e Veterinárias, Campus Jaboticabal, em quatro períodos de 28 dias, totalizando 112 dias de duração.

As instalações utilizadas foram galpões convencionais de postura ( $3 \mathrm{~m}$ de largura, $20 \mathrm{~m}$ de comprimento e $2 \mathrm{~m}$ de pé-direito), compostos internamente por gaiolas de arame galvanizado com quatro compartimentos de $25 \times 40 \times 40 \mathrm{~cm}$, distribuídas lateralmente em dois andares distantes $0,80 \mathrm{~m}$ do piso. O comedouro utilizado foi do tipo calha galvanizada, percorrendo toda extensão frontal das gaiolas, e o bebedouro, do tipo taça.

Utilizaram-se 180 poedeiras comerciais da linhagem Isa Brown com 60 semanas de idade e em primeiro ciclo de produção, distribuídas em 30 parcelas de seis aves. Inicialmente, as aves foram selecionadas de acordo com o peso corporal (1.900 $\pm 50 \mathrm{~g}$ ) para uniformização do lote e, por um período de quatro semanas, a produção foi controlada individualmente para posterior redistribuição nas parcelas para equalização da produção (85,5 \pm 7\%).

Durante todo o período experimental, as aves receberam água e ração à vontade, e o consumo de ração foi quantificado ao final de cada período. O regime de iluminação adotado foi o de 17 horas de luz por dia, utilizando-se timer para controle do fornecimento de luz suplementar.

O delineamento utilizado foi o inteiramente casualizado com cinco tratamentos, cada um com seis repetições de seis aves, totalizando 180 aves em 30 parcelas. Os tratamentos foram arranjados em esquema fatorial $2 \times 2+1$, com dois níveis de fitase ( 0 e $500 \mathrm{FTU} / \mathrm{kg}$ de ração, considerando ou não a matriz nutricional), dois níveis de substituição do milho por sorgo (50 e 100\%) e uma ração testemunha (isenta de sorgo e fitase).

As rações experimentais utilizadas foram formuladas para serem isocalóricas, isocálcicas e isoproteicas (Tabela 1), e calculadas para atender às recomendações mínimas, de acordo com Rostagno et al. (2005). Além da ração testemunha, com milho e farelo de soja e sem adição de fitase, utilizaram-se duas rações com $50 \%$ ou $100 \%$ de substituição do milho por sorgo, sem adição de fitase ( 500 FTU/kg de ração) e duas com a enzima fitase. A enzima utilizada foi a Natuphos 10.000G, marca registrada da empresa BASF, obtida pela fermentação com fungos do grupo Aspergillus niger, contendo atividade inicial mínima declarada pelo fabricante de 10.000 FTU/g. Uma unidade de fitase (FTU) é definida como a quantidade de enzima necessária para liberar um micromol de fósforo inorgânico em um minuto em um substrato de sódiofitato a temperatura de $37^{\circ} \mathrm{C}$ e no $\mathrm{pH}$ 5,5. A matriz nutricional de fitase utilizada na formulação das rações foi de $2.959 \%$ de proteína bruta (158\% de lisina, 53\% de metionina+cistina e $171 \%$ de treonina), $697.056 \mathrm{kcal} / \mathrm{kg}$ de energia metabolizável aparente, 2.192\% de cálcio e 2.521\% de fósforo disponível. A matriz nutricional indica a quantidade de nutrientes (energia, proteína, cálcio, fósforo e aminoácidos) que será liberada quando a fitase é acrescentada à ração. Dessa forma, considerou-se que as rações contendo fitase apresentaram redução nos níveis 
Tabela 1 - Composição em ingredientes e níveis nutricionais das rações experimentais

\begin{tabular}{|c|c|c|c|c|c|c|}
\hline \multirow[t]{2}{*}{ Ingrediente (\%) } & \multirow[b]{2}{*}{ Custo $(\mathrm{R} \$ / \mathrm{kg})$} & \multirow[b]{2}{*}{ Testemunha } & \multicolumn{2}{|c|}{ Sem fitase } & \multicolumn{2}{|c|}{ Com fitase } \\
\hline & & & $50 \%$ Sorgo & $100 \%$ Sorgo & $50 \%$ Sorgo & $100 \%$ Sorgo \\
\hline Milho grão & 0,47 & 64,98 & 30,95 & 0,00 & 32,58 & 0,00 \\
\hline Calcário calcítico & 0,10 & 8,85 & 8,84 & 8,85 & 9,00 & 9,01 \\
\hline Sorgo & 0,42 & 0,00 & 30,95 & 61,69 & 32,58 & 64,00 \\
\hline Óleo de soja & 2,40 & 2,11 & 3,80 & 5,04 & 2,60 & 4,01 \\
\hline Suplemento vitamínico + mineral* & 5,30 & 0,40 & 0,40 & 0,40 & 0,40 & 0,40 \\
\hline L-lisina $\mathrm{HCl}(78 \%)$ & 4,45 & 0,08 & 0,05 & 0,09 & 0,08 & 0,10 \\
\hline DL-metionina (98\%) & 22,13 & 0,08 & 0,09 & 0,12 & 0,09 & 0,12 \\
\hline Antioxidante & 6,50 & 0,02 & 0,02 & 0,02 & 0,02 & 0,02 \\
\hline Fitase & 26,69 & 0,00 & 0,00 & 0,00 & 0,005 & 0,005 \\
\hline Total & - & 100 & 100 & 100 & 100 & 100 \\
\hline Proteína bruta (\%) & & 15,45 & 15,45 & 15,45 & 15,45 & 15,45 \\
\hline Cálcio (\%) & & 3,82 & 3,82 & 3,82 & 3,82 & 3,82 \\
\hline Fósforo total (\%) & & 0,53 & 0,54 & 0,54 & 0,41 & 0,41 \\
\hline Fósforo disponível (\%) & & 0,34 & 0,34 & 0,34 & 0,34 & 0,34 \\
\hline Lisina total $(\%)$ & & 0,82 & 0,82 & 0,82 & 0,82 & 0,82 \\
\hline Metionina total (\%) & & 0,47 & 0,47 & 0,49 & 0,50 & 0,48 \\
\hline Met. + cistina total (\%) & & 0,74 & 0,74 & 0,74 & 0,74 & 0,74 \\
\hline Treonina total $(\%)$ & & 0,60 & 0,60 & 0,60 & 0,60 & 0,60 \\
\hline Triptofano total (\%) & & 0,18 & 0,18 & 0,19 & 0,19 & 0,19 \\
\hline Lisina digestível (\%) & & 0,74 & 0,74 & 0,74 & 0,74 & 0,74 \\
\hline Metionina + cistina digestível (\%) & & 0,67 & 0,67 & 0,67 & 0,67 & 0,67 \\
\hline Metionina digestível (\%) & & 0,45 & 0,45 & 0,45 & 0,47 & 0,45 \\
\hline Treonina digestível (\%) & & 0,52 & 0,52 & 0,52 & 0,52 & 0,52 \\
\hline
\end{tabular}

* Enriquecimento por kg de ração: vit. A - 6.250 UI; vit. D3 - 2.500 UI; vit. E - 13 mg; vit. K3 - 1 mg; vit. B1 - 1,5 mg; vit. B2 - 3,4 mg; vit. B6 - 1 mg, vit. B12 - 20 mcg; ácido fólico - 0,25 mg; ácido pantotênico 2,85 mg; niacina - 30 mg; biotina - 0,1 mg; colina - 0,24 mg; cobre - 7,5 mg; zinco - 60 mg; manganês - 46 mg; iodo - 1 mg; selênio - 0,2 mg; antioxidante (BHT) - 0,4 mg.

de energia metabolizável aparente (35 kcal/kg), proteína (0,15\%), cálcio $(0,11 \%)$, fósforo $(0,13 \%)$, metionina + cistina $(0,003 \%)$, lisina $(0,008 \%)$ e treonina $(0,0085 \%)$.

Ao final de cada período, o desempenho das aves foi avaliado por meio dos dados de consumo de ração (g/ave/dia), produção de ovos (\%), massa de ovos (g), peso dos ovos (g) e conversão alimentar (kg de ração/kg de ovo).

Os parâmetros relativos à qualidade dos ovos foram avaliados durante os dois últimos dias de cada período, onde foram coletados aleatoriamente três ovos por repetição para determinação da espessura de casca (mm), unidades haugh, porcentagem de casca e índice de pigmentação da gema (leque colorimétrico da $\mathrm{DSM}^{\circledR}$ ). A gravidade específica $\left(\mathrm{g} / \mathrm{cm}^{3}\right)$ foi determinada com todos os ovos íntegros produzidos nas últimas 24 horas dos dois dias de avaliação, adotando-se o procedimento de soluções de $\mathrm{NaCl}$, de acordo com recomendação de Moreng \& Avens (1990), de modo que, entre as soluções, a densidade variou de 1,065 a $1,100 \mathrm{~g} / \mathrm{cm}^{3}$ com gradiente de 0,005 entre as medidas.
Ao final do experimento, foi realizado um ensaio de metabolismo para quantificar os teores de fósforo (P) e nitrogênio $(\mathrm{N})$ nas rações e nas excretas de poedeiras comerciais e calcular a ingestão, excreção e retenção aparente desses nutrientes. Foi utilizado o método de coleta total de excretas. O ensaio teve duração de 10 dias: cinco de adaptação e cinco de coletas (duas vezes ao dia). Foi adicionado 1,0\% de óxido férrico em todas as rações, no primeiro e no último dia, como marcador do início e do término da coleta das excretas. Ao término do período, as amostras de cada parcela, assim como de cada ração utilizada, foram enviadas ao laboratório para quantificação dos teores de matéria seca, fósforo e nitrogênio de acordo com as metodologias descritas por Silva (1990).

Ao final do período experimental, foi realizada ainda uma avaliação econômica. Para os custos de produção foi considerado apenas o custo com a ração, uma vez que todos os outros custos foram os mesmos para todos os tratamentos experimentais. O custo da ração para produzir uma dúzia de 
ovos ou um quilograma de ovos foi determinado considerando a quantidade de ração necessária para a produção de uma dúzia ou de um quilograma de ovos e o preço por quilograma de ração. O custo das rações foi determinado considerando a composição das rações e o preço dos ingredientes obtidos em junho de 2008.

Os dados de desempenho, qualidade dos ovos e ingestão, excreção e retenção aparente de fósforo e nitrogênio foram submetidos à análise de variância pelo procedimento General Linear Model (GLM) do programa SAS $^{\circledR}$ (SAS, 2002) e as médias foram comparadas pelo teste de Tukey a $5 \%$ de probabilidade.

\section{Resultados e Discussão}

Não houve interação entre os níveis de substituição de sorgo e os níveis de inclusão de fitase $(\mathrm{P}>0,05)$ para as características de desempenho analisadas (Tabela 2). Os níveis de substituição do milho pelo sorgo não afetaram $(\mathrm{P}>0,05)$ os parâmetros de desempenho avaliados. Esses resultados estão de acordo com os relatados por Casartelli et al. (2005) e Assuena et al. (2008), que, avaliando diferentes formas de atendimento das exigências de aminoácidos e substituição parcial ou total do milho pelo sorgo em rações para poedeiras comerciais, também não observaram efeito negativo no desempenho das aves.

A adição de fitase só afetou $(\mathrm{P}>0,05)$ o peso dos ovos, de maneira que as aves que receberam rações com níveis nutricionais reduzidos e suplementadas com fitase produziram ovos mais leves (66,20 g) em comparação àquelas que receberam rações com níveis nutricionais normais e sem fitase (67,82 g). Da mesma forma, Carlos \& Edwards (1998) também verificaram efeito negativo no peso dos ovos produzidos por poedeiras entre 24 a 32 semanas de idade alimentadas com rações à base de milho e farelo de soja contendo 0,10\% de fósforo não fítico e 600 FTU/kg de ração.

Por outro lado, Gordon \& Roland (1997) observaram diminuição no peso dos ovos das aves que consumiram rações com 0,10\% de fósforo disponível e isentas de fitase, porém quando adicionada fitase (300 FTU/kg de ração), este efeito adverso foi corrigido.

A diminuição do peso dos ovos neste experimento poderia ser explicada por diversos fatores dietéticos como proteína, metionina, lisina e energia (Grobas \& Mateos, 1999). As rações com adição de fitase, em virtude da valorização de sua matriz nutricional, podem ter apresentado menores níveis desses nutrientes, ou seja, não disponibilizaram a quantia esperada de energia, proteína e aminoácidos contidos nos ingredientes vegetais que estariam ligados ao fitato.

Por outro lado, para os demais parâmetros que também poderiam ser afetados, como produção de ovos, não foram observadas diferenças $(\mathrm{P}>0,05)$, o que indica que a matriz nutricional preconizada para fitase atendeu plenamente às exigências das aves, mesmo quando utilizadas rações com níveis nutricionais reduzidos, semelhante ao observado por Fernandes et al. (2003) e Shelton et al. (2004) para frangos de corte, cuja valorização nutricional da fitase permitiu a utilização de rações com níveis nutricionais reduzidos sem prejuízo ao desempenho das aves.

Da mesma forma, Bess et al. (2006) não encontraram diferenças significativas na porcentagem de postura em matrizes de frango de corte alimentadas com rações com valorização plena da matriz nutricional da fitase. Esses

Tabela 2 - Desempenho de poedeiras comerciais alimentadas no período de 64 a 80 semanas de idade com rações contendo sorgo em substituição ao milho e dois níveis de fitase

\begin{tabular}{|c|c|c|c|c|c|c|}
\hline & \multirow[t]{2}{*}{ Fitase (FTU) } & \multicolumn{2}{|c|}{ Sorgo (\%) } & \multirow[t]{2}{*}{ Média } & \multirow[t]{2}{*}{ Testemunha } & \multirow[t]{2}{*}{ CV (\%) } \\
\hline & & 50 & 100 & & & \\
\hline \multirow[t]{3}{*}{ Consumo (g/ave/dia) } & 500 & 100,01 & 98,24 & 99,12 & & \\
\hline & 0 & 103,07 & 99,36 & 101,22 & 101,72 NS & 3,29 \\
\hline & Média & 101,54 & 98,80 & 100,17 & & \\
\hline \multirow[t]{3}{*}{ Produção de ovos (\%) } & 500 & 81,40 & 80,40 & 80,90 & & \\
\hline & 0 & 82,80 & 82,40 & 82,60 & $80,10 \mathrm{NS}$ & 5,34 \\
\hline & Média & 82,08 & 81,40 & 81,75 & & \\
\hline \multirow[t]{3}{*}{ Peso do ovo (g) } & 500 & 65,81 & 66,60 & $66,20 \mathrm{~B}$ & & \\
\hline & 0 & 67,64 & 68,00 & $67,82 \mathrm{~A}$ & $66,70 \mathrm{NS}$ & 2,79 \\
\hline & Média & 66,72 & 67,30 & 67,01 & & \\
\hline \multirow[t]{3}{*}{ Massa de ovos (g/ave/dia) } & 500 & 53,54 & 53,54 & 53,54 & & \\
\hline & 0 & 56,00 & 55,60 & 55,98 & 53,38 NS & 5,73 \\
\hline & Média & 54,76 & 54,76 & 54,76 & & \\
\hline \multirow[t]{3}{*}{ Conversão alimentar (kg/kg) } & 500 & 1,88 & 1,84 & 1,86 & & \\
\hline & 0 & 1,82 & 1,78 & 1,80 & $1,91 \mathrm{NS}$ & 6,39 \\
\hline & Média & 1,85 & 1,81 & 1,83 & & \\
\hline
\end{tabular}

Médias na coluna seguidas de diferentes letras maiúsculas diferem $(\mathrm{P}>0,05)$ pelo teste de Tukey.

São apresentadas também as comparações das médias entre fatoriais e a testemunha, sendo NS $=\mathrm{P}>0,05$. 
autores observaram que os níveis nutricionais reduziram, em comparação aos das aves que receberam a ração testemunha, com níveis nutricionais adequados e sem adição de fitase.

Gordon \& Roland (1997) e Boling et al. (2000), em experimento no qual não consideraram a matriz nutricional da fitase, também não observaram diferenças significativas para a porcentagem de postura em poedeiras comerciais alimentadas com rações contendo níveis reduzidos de fósforo disponível (Pd) em até $78 \%$ (0,10\% de Pd) e com fitase em relação às aves alimentadas com a ração testemunha (0,45\% de Pd).

Por outro lado, Keshavarz (2003) e Lim et al. (2003) observaram melhora na porcentagem de postura em poedeiras comerciais alimentadas com rações à base de milho e farelo de soja, contendo 0,25 ou $0,15 \%$ de Pd e 300 FTU de fitase/kg de ração, em comparação às aves alimentadas com a ração controle $(0,45 \%$ de Pd). Além disso, Keshavarz (2003) verificou melhora no peso de ovos, massa de ovos e conversão alimentar.

Na análise da qualidade dos ovos (Tabela 3), só houve interação significativa entre os níveis de fitase e os de sorgo para o índice de pigmentação de gema $(\mathrm{P}<0,01)$. A média do índice de pigmentação da gema dos ovos produzidos pelas aves alimentadas com a ração testemunha foi superior à média das aves alimentadas com as rações contendo dois níveis de substituição de milho pelo sorgo (50 e 100\%) e dois níveis de fitase (0 e 500 FTU de fitase/kg de ração), correspondendo a um valor de 8,37 e 4,41, respectivamente. Esse resultado se deve principalmente aos níveis de substituição do milho pelo sorgo, o qual possui menor quantidade de carotenoides responsáveis pela pigmentação da gema em comparação à quantidade presente no milho.

Não foi observada interação entre os níveis de substituição do milho pelo sorgo e os níveis de adição de fitase $(\mathrm{P}>0,05)$ para a qualidade dos ovos. Entretanto, isoladamente, os níveis de substituição do milho pelo sorgo influenciaram o índice de pigmentação de gema ( $P<0,01)$ e a espessura de casca $(\mathrm{P}<0,05)$.

As aves alimentadas com rações contendo o menor nível de sorgo (50\%) produziram ovos com gemas de maiores índices de pigmentação $(6,30)$ em relação àquelas alimentadas com rações com substituição total do milho pelo sorgo $(2,52)$. Diminuição do índice de pigmentação das gemas com o aumento do nível de sorgo nas rações de poedeiras também foi relatada por Casartelli et al. (2005) e Assuena et al. (2008), que destacaram a necessidade de se adicionar às rações uma fonte de carotenoides.

O menor nível de substituição do sorgo produziram ovos com maior espessura de casca $(0,360 \mathrm{~mm})$ em relação ao maior nível de substituição $(0,350 \mathrm{~mm})$. De acordo com Brugalli et al. (1998), o aumento no nível de óleo da ração pode determinar aumento na deposição de gordura na glândula da casca, o que acaba comprometendo sua qualidade. Neste experimento o aumento da inclusão de sorgo determinou também aumento na inclusão de óleo. Essa diminuição, no entanto, não foi observada por Casartelli et al. (2005) e Assuena et al. (2008).

Os níveis de fitase não influenciaram $(\mathrm{P}>0,05)$ as características de qualidade dos ovos, exceto o índice de pigmentação de gema $(\mathrm{P}<0,05)$. A média da pigmentação de gema dos ovos produzidos por aves alimentadas com

Tabela 3 - Qualidade dos ovos de poedeiras comerciais alimentadas no período de 64 a 80 semanas de idade com rações contendo sorgo em substituição ao milho e dois níveis de fitase

\begin{tabular}{|c|c|c|c|c|c|c|}
\hline & \multirow[t]{2}{*}{ Fitase (FTU/kg) } & \multicolumn{2}{|c|}{ Sorgo (\%) } & \multirow[t]{2}{*}{ Média } & \multirow[t]{2}{*}{ Testemunha } & \multirow[t]{2}{*}{ CV (\%) } \\
\hline & & 50 & 100 & & & \\
\hline \multirow[t]{3}{*}{ Unidade Haugh } & 500 & 88,17 & 86,40 & 87,29 & & 2,99 \\
\hline & 0 & 86,35 & 88,31 & 87,33 & $87,68 \mathrm{NS}$ & \\
\hline & Média & 87,26 & 87,36 & 87,31 & & \\
\hline \multirow[t]{3}{*}{$\%$ de casca } & 500 & 8,95 & 8,64 & 8,80 & & 3,08 \\
\hline & 0 & 8,76 & 8,68 & 8,72 & $8,84 \mathrm{NS}$ & \\
\hline & Média & 8,85 & 8,66 & 8,76 & & \\
\hline \multirow[t]{3}{*}{ Espessura de casca (mm) } & 500 & 0,360 & 0,350 & 0,350 & & 2,89 \\
\hline & 0 & 0,360 & 0,350 & 0,360 & $0,36 \mathrm{NS}$ & \\
\hline & Média & $0,360 \mathrm{a}$ & $0,350 \mathrm{~b}$ & 0,350 & & \\
\hline \multirow[t]{3}{*}{ Gravidade específica } & 500 & 1,0862 & 1,0851 & 1,0856 & & 0,17 \\
\hline & 0 & 1,0850 & 1,0845 & 1,0847 & $1,0848 \mathrm{NS}$ & \\
\hline & Média & 1,0856 & 1,0848 & 1,0851 & & \\
\hline \multirow[t]{3}{*}{ Índice de pigmentação de gema } & 500 & 6,10 & 2,48 & 4,29B & & 4,80 \\
\hline & 0 & 6,50 & 2,55 & $4,52 \mathrm{~A}$ & $8,37 * *$ & \\
\hline & Média & $6,30 \mathrm{a}$ & $2,52 b$ & 4,41 & & \\
\hline
\end{tabular}

Médias na coluna (linha) seguidas de letras maiúsculas (minúsculas) diferentes diferem $(\mathrm{P}<0,05)$ pelo teste de Tukey.

São apresentadas também a comparação das médias entre fatoriais e testemunha, sendo $* *=\mathrm{P}<0,01$ e NS $=\mathrm{P}>0,05$. 
rações suplementadas com fitase foi inferior à das aves alimentadas com dietas sem fitase, cujos valores foram 4,29 e 4,52, respectivamente.

A ausência do efeito dos níveis de fitase sobre a unidade haugh observada no presente estudo, está de acordo com os resultados obtidos por Jalal \& Scheideler (2001), que não observaram diferenças para Unidade Haugh avaliando poedeiras de 40 a 60 semanas de idade alimentadas com rações contendo diferentes níveis de $\operatorname{Pd}(0,25 ; 0,15$; e 0,10\%) e com fitase (250 e 300 FTU de fitase/kg de ração) em comparação a aves que receberam a ração convencional com $0,35 \%$ de fósforo disponível. O aumento na disponibilidade de fósforo garante a qualidade da casca e melhor qualidade interna.

Neste estudo a utilização da matriz da fitase preconizada pelo fabricante mostrou-se eficiente em garantir a qualidade externa dos ovos. Bess et al. (2006) avaliaram o efeito da matriz fítica sobre a qualidade externa dos ovos em matrizes de frango de corte e também observaram que a matriz nutricional preconizada para fitase atendeu às exigências das aves, mesmo quando os níveis de fósforo foram reduzidos.

Desta maneira, quando utilizada a fitase, é necessário o conhecimento de sua matriz nutricional, ou seja, o quanto ela disponibilizará dos ingredientes de origem vegetal para a ave, evitando o fornecimento em excesso ou em déficit de nutrientes para ótimo desempenho e qualidade dos ovos.

Para consumo e excreção de fósforo (Tabela 4), ocorreram interações significativas entre o fatorial e testemunha $(\mathrm{P}<0,01)$. Observa-se que as aves que foram alimentadas com a ração testemunha apresentaram maior ingestão de $\mathrm{P}$ e conseqüentemente maior excreção do mesmo.

Da mesma forma, o consumo e a excreção de fósforo foram afetados $(\mathrm{P}<0,01)$ pelos níveis de fitase. As aves que receberam rações com níveis nutricionais reduzidos e suplementadas com fitase consumiram menor quantidade de fósforo (315,00 g) em relação àquelas que receberam rações com níveis nutricionais normais e sem fitase (408,66 g), consequentemente, as aves alimentadas com rações contendo fitase apresentaram redução de $27 \%$ na excreção de fósforo em relação às aves alimentadas com dietas sem fitase. Esse fato se deve, principalmente, à diminuição de $51 \%$ na quantidade de fosfato bicálcico incluída na formulação das dietas quando valorizada a matriz fítica, ou seja, a quantidade de fósforo fítico que a fitase teoricamente disponibilizará dos ingredientes de origem vegetal.

Boling et al. (2000) e Keshavarz (2003) também observaram decréscimo na excreção de fósforo (50 e 56\%, respectivamente) e ausência de efeito negativo sobre o desempenho de poedeiras quando forneceram dietas com níveis de fosfato bicálcico reduzidos em até 67 e 78\%, respectivamente, e suplementadas com $300 \mathrm{FTU}$ de fitase $/ \mathrm{kg}$ de ração.

De acordo com Simons et al. (1990), reduzir a suplementação de fósforo inorgânico e aumentar o uso do fósforo fítico pelo animal pelo uso de fitase pode

Tabela 4 - Consumo, excreção e retenção aparente de fósforo e nitrogênio em poedeiras comerciais alimentadas no período de 64 a 80 semanas de idade com rações contendo sorgo em substituição ao milho e dois níveis de fitase

\begin{tabular}{|c|c|c|c|c|c|c|}
\hline & \multirow[t]{2}{*}{ Fitase (ftu/kg) } & \multicolumn{2}{|c|}{ Sorgo (\%) } & \multirow[t]{2}{*}{ Média } & \multirow[t]{2}{*}{ Testemunha } & \multirow[t]{2}{*}{ CV (\%) } \\
\hline & & 50 & 100 & & & \\
\hline \multirow[t]{3}{*}{ Consumo de fósforo (mg/ave.dia) } & 500 & 326,00 & 304,00 & $315,00 \mathrm{~B}$ & & 4,03 \\
\hline & 0 & 412,00 & 405,33 & $408,66 \mathrm{~A}$ & $456,66^{* *}$ & \\
\hline & Média & 369,00 & 354,66 & 361,83 & & \\
\hline \multirow[t]{3}{*}{ Excreção de fósforo (mg/ave.dia) } & 500 & 252,33 & 217,00 & $234,66 \mathrm{~B}$ & & 8,81 \\
\hline & 0 & 321,00 & 321,66 & $321,33 \mathrm{~A}$ & $375,00 * *$ & \\
\hline & Média & 286,66 & 269,33 & 277,99 & & \\
\hline \multirow[t]{3}{*}{ Fósforo retido (\%) } & 500 & 22,84 & 28,61 & 25,72 & & 28,99 \\
\hline & 0 & 21,96 & 20,75 & 21,35 & $17,79 \mathrm{NS}$ & \\
\hline & Média & 22,40 & 24,68 & 23,54 & & \\
\hline \multirow[t]{3}{*}{ Consumo nitrogênio (g/ave.dia) } & 500 & 2,06 & 2,16 & 2,11 & & 4,74 \\
\hline & 0 & 2,17 & 2,23 & 2,20 & $2,11 \mathrm{NS}$ & \\
\hline & Média & 2,11 & 2,19 & 2,15 & & \\
\hline \multirow[t]{3}{*}{ Excreção nitrogênio (g/ave.dia) } & 500 & 1,08 & 1,18 & 1,13 & & 8,15 \\
\hline & 0 & 1,20 & 1,17 & 1,18 & $1,17 \mathrm{NS}$ & \\
\hline & Média & 1,14 & 1,17 & 1,16 & & \\
\hline \multirow[t]{3}{*}{$\% \mathrm{~N}$ retido } & 500 & 47,26 & 44,98 & 46,12 & & 7,31 \\
\hline & 0 & 44,53 & 47,40 & 45,96 & $44,31 \mathrm{NS}$ & \\
\hline & Média & 45,89 & 46,19 & 46,04 & & \\
\hline
\end{tabular}

Médias na coluna seguidas de diferentes letras maiúsculas diferem $(\mathrm{P}<0,05)$ pelo teste de Tukey.

São apresentadas também comparações das médias entre fatoriais e testemunha sendo $* *=\mathrm{P}<0,01$ e NS $=\mathrm{P}>0,05$. 
proporcionar diminuição de 20 a 30\% na excreção do fósforo e redução significativa nos custos com alimentação.

O consumo, a excreção e a retenção de nitrogênio não foram influenciados pelos níveis de fitase ( $\mathrm{P}>0,05)$, o que contraria os relatos de Nahashon et al. (1994) de que a adição de fitase em dietas com 0,25\% de Pd para poedeiras promove aumento de $25 \%$ na retenção de nitrogênio em relação ao grupo testemunha, evidenciando a eficácia de fitase em hidrolisar a ligação entre o fitato e a proteína, disponibilizando esse nutriente para as aves. Os níveis de substituição do milho pelo sorgo não ocasionaram diferença nessas variáveis $(\mathrm{P}>0,05)$, provavelmente em virtude da semelhança nos teores de fósforo desses dois alimentos. Da mesma forma, não foi observada interação entre os níveis de substituição de sorgo e os níveis de fitase $(\mathrm{P}>0,05)$.

A substituição parcial ou total do milho pelo sorgo sem adição de fitase determinou aumento numérico médio de 1,57\% no custo das rações (Tabela 5), o que está relacionado à adição de óleo de soja, necessária pelo fato de o sorgo possuir baixo teor de energia metabolizável. Por outro lado, quando adicionada a enzima fitase, o custo reduziu 6,18\% e se tornou, inclusive, $4,68 \%$ inferior ao custo da ração testemunha, em decorrência da menor inclusão do farelo de soja, do óleo de soja e do fosfato bicálcico à dieta. Isso ocorreu em razão da valorização da matriz da enzima fitase.

A substituição parcial do milho pelo sorgo determinou redução no custo de produção por quilograma ou dúzia de ovos, que se tornou ainda mais acentuada à medida que foi adicionada fitase. A redução média no custo/kg de ovo e por dúzia de ovos com a subsbtituição total do milho pelo sorgo com a inclusão de fitase foi de 7,53\% e 7,78\%, respectivamente.

Tabela 5 - Custo de rações formuladas com substituição do milho pelo sorgo e com adição de fitase

\begin{tabular}{lcccc}
\hline & Fitase & \multicolumn{2}{c}{ Sorgo (\%) } & \multirow{2}{*}{ Testemunha } \\
\cline { 2 - 4 } & & 50 & 100 & \\
\hline Custo da ração (R\$/kg) & 500 & 0,575 & 0,579 & 0,604 \\
& 0 & 0,613 & 0,614 & \\
Custo/kg de ovo (R\$/kg) & 500 & 1,079 & 1,068 & 1,155 \\
& 0 & 1,090 & 1,090 & \\
Custo/dúzia de ovos & 500 & 0,853 & 0,852 & 0,925 \\
(R\$/dúzia) & & & & \\
\hline
\end{tabular}

\section{Conclusões}

A utilização do sorgo em substituição total ao milho e a valorização da matriz nutricional da enzima fitase na composição de rações não comprometem o desempenho das aves e ainda reduzem a excreção de fósforo e o custo de produção. Essa estratégia, entretanto, exige a utilização de pigmentantes para não comprometer a coloração da gema do ovo.

\section{Literatura Citada}

ASSUENA, V.; FILARDI, R.S.; JUNQUEIRA, O.M. et al. Substituição do milho pelo sorgo em rações para poedeiras comerciais formuladas com diferentes critérios de atendimento das exigências em aminoácidos. Ciência Animal Brasileira, v.9, p.93-99, 2008.

BESS, F.; ROSA, A.P.; KRABBE, E.L. et al. Efeito da adição de fitase sobre a percentagem de postura e densidade de ovos em matrizes de corte. Revista Brasileira de Ciência e Tecnologia Avícola, v.8, n.2, p.106, 2006.

BOLING, S.D.; DOUGLAS, M.W.; SHIRLEY, R.B. et al. The effects of various dietary levels of phytase and avaible phosphorus on performance of laying hens. Poultry Science, v.79, n.3-4, p.535-538, 2000.

BRUGALLI, I.; RUTZ, F.; ZONTA, E.P. et al. Efeito dos níveis de óleo e proteína da dieta sobre a qualidade interna de ovos, em diferentes condições e tempo de armazenamento. Revista Brasileira de Agrociência, v.4, n.3, p.187-190, 1998.

CARLOS, A.B.; EDWARDS JR., H.M. The effects of 1,25Dihydroxycholecalciferol and phytase on the natural phytase phosphorus utilization by laying hens. Poultry Science, v.77, n.6, p.850-858, 1998.

CASARTELLI, E.M.; FILARDI, R.S.; JUNQUEIRA, O.M. Utilização do sorgo em rações para poedeiras comerciais formuladas com diferentes recomendações de aminoácidos In: REUNÃO ANUAL DA SOCIEDADE BRASILEIRA DE ZOOTECNIA, 42., 2005, Goiânia. Anais... Goiânia: Sociedade Brasileira de Zootecnia (CD-ROM).

FERNANDES, E.A.; HONSI-BRANDEBURGO, M.I.; SILVEIRA, M.M. et al. Avaliação da adição de fitase em dietas de frangos de corte. Revista Brasileira de Ciência Avícola, supl. 5, p.33, 2003.

GORDON, R.W.; ROLAND, D.A. Influence of supplemental phytase on calcium and phosphorus utilization in laying hens. Poultry Science, v.77, p.290-294, 1998.

GORDON, R.W.; ROLAND, D.A. Performance of commercial laying hens fed various phosphorus levels, with and without supplemental phytase. Poultry Science, v.76, n.8, p.1172-1177, 1997.

GROBAS, S.; MATEOS, G.G. influence of dietary linoleic acid on production and weight of eggs and egg components in young brown hens. Journal Applied Poultry Research, v.8, n.2, p.177-184, 1999.

JALAL, M.A.; SHEIDELER, S.E. Effect of supplementation of two different sources of phytase on egg production parameters in laying hens and nutrient digestibility. Poultry Science, v.80, p.1463-1471, 2001.

KESHAVARZ, K. The effect of different levels of nonphytate phosphorus with and without phytase on the performance of four strains of laying hens. Poultry Science, v.82, p.71-91, 2003.

LAURENTIZ, A.C.; JUNQUEIRA, O.M.; FILARDI, R.S. et al. Efeito da adição da enzima fitase em rações para frangos de corte com redução dos níveis de fósforo nas diferentes fases de criação. Ciência Animal Brasileira, v.8, p.207-216, 2007.

LIM, H.S.; NAMKUNG, H.; PAIK, I.K. Effects of phytase supplementation on the performance, egg quality, and phosphorous excretion of laying hens fed different levels of dietary calcium and nonphytate phosphorous. Poultry Science, v.82, p.92-99, 2003.

MORENG, R.E.; AVENS, J.S. Ciência e produção de aves. São Paulo: Roca, 1990. 380p. 
NAHASHON, S.N.; NAKAUE, H.S.; MIROSh, L.W. Phytase activity phosphorus and calcium retention, and performance of single comb White Leghorn layers fed diets containing two levels of available phosphorus and supplemented with directfeed microbials. Poultry Science, v.73, p.1552-1562, 1994.

NAMKUNG, H.; LEESON, S. Effect of phytase enzyme on dietary nitrogen-corrected apparent metabolizable energy and the ileal digestibility of nitrogen and amino acids in broiler chicks. Poultry Science, v.78, p.1317-1319, 1999.

ROSTAGNO, H.S.; ALBINO, L.F.T.; DONZELE, J.L. et al. Tabelas brasileiras de exigências nutricionais para aves e suínos (Composição de alimentos e exigências nutricionais). 2.ed. Viçosa, MG: Universidade Federal de Viçosa, 2005. 186p.

SEBASTIAN, S.; TOUCHBURN, S.P.; CHAVEZ, E.R. Apparent digestibility of protein and amino acids in broiler chickens fed a corn-soybean diet supplemented with microbial phytase. Poultry Science, v.76, p.1760-1769, 1997.

SEBASTIAN, S.; TOUCHBURN, S.P.; CHAVEZ, E.R. Implication of phytic acid and supplemental microbial phytase in poultry nutrition: a rewiew. World's Poultry Science Journal, v.54, p.27-47, 1998.

SHELTON, J.L.; SOUTHERN, L.L.; GASTON, L.A. et al. Evaluation of the nutrient Matrix Values for phytase in broilers. Journal Applied Poultry Research, v.13, p.213-221, 2004.

SILVA, D.J. Análise de alimentos (métodos químicos e biológicos). Viçosa, MG: Universidade Federal de Viçosa, 1990. 166p.

SIMONS, P.C.M.; VERSTEEGH, H.A.V.; JONGLOED, A.W. et al. Improvement of phosphorus availability by microbial phytase in broilers and pig. British Journal Nutrition, v.64, p.525-540, 1990.

STATISTICAL ANALYSIS SYSTEM - SAS. Institute SAS ${ }^{\circledR}$ user' guide: statistics. Version 8.2. Cary: 2002. (CD-ROM). 